\title{
SETE NOVAS CIDADES DE MATO GROSSO
}

\author{
SEVEN NEW CITIES OF MATO GROSSO
}

Vicente Barcellos*

\section{RESUMO}

presente artigo tem como foco o estudo de sete novas cidades surgidas em Mato Grosso a partir da década de 1970 como resultado das políticas públicas de colonização promovidas durante o regime militar no arco de terras que envolve a Amazônia, e que acabou resultando no avanço da chamada fronteira agrícola, a qual, no final da década de 1990, se consolida com o desenvolvimento da moderna produção agrícola que se expande na Região Centro-Oeste. Se no início esses processos fizeram surgir inúmeros povoados que funcionavam como simples núcleos de apoio aos colonos que chegavam, mais tarde esses povoados se transformaram em dinâmicas cidades-sedes de novos municípios envolvidos no agronegócio. São consideradas no presente artigo as cidades de Sinop, Sorriso, Lucas do Rio Verde, Nova Mutum, Campo Novo do Parecis, Campo Verde e Primavera do Leste.

Palavras-chave: Novas cidades. Novas paisagens urbanas. Urbanização de Mato Grosso. Novas cidades do cerrado.

\section{ABSTRACT}

This article focuses on the study of seven new cities in Mato Grosso emerged from the 1970s as a result of public policies of colonization promoted during the military regime in the arc of land surrounding the Amazônia and eventually resulted in the advancement of call agricultural frontier, which in late 1990 was consolidated with the development of modern agricultural production expands in the Midwest. If earlier these processes have raised numerous villages that functioned as simple cores support the settlers who came later these villages became dynamic host cities of new municipalities involved in agribusiness. Are examined in this article the cities of Sinop, Sorriso, Lucas do Rio Verde, Nova Mutum, Campo Novo do Parecis Campo Verde and Primavera do Leste.

Keywords: New cities. New urban landscape. Urbanization in Mato Grosso. New towns in the cerrado.

\section{INTRODUÇÃO}

Os processos de colonização a serem vistos neste artigo tiveram início durante o regime militar, resultando no chamado avanço da fronteira agrícola brasileira. Esta se consolidou na década de 1990 pelo desenvolvimento de uma moderna produção de grãos, que, ao contrário do que se costuma pensar, não se limita à monocultura de soja - embora esta seja a produção mais visível, pela expressiva participação na pauta de exportações brasileira -, mas inclui, também, a produção de milho, algodão, sorgo, feiião e outros grãos.

Num contexto que parecia fadado ao extrativismo, à pecuária e à agricultura de subsistência, surge em Mato Grosso uma moderna agricultura, que provoca transfor-

Professor associado da Faculdade de Arquitetura e Urbanismo da Universidade de Brasília (FAU/UnB). Coordenador do Núcleo de Pesquisa Quadros do Paisagismo no Brasil, QUAPÁ-SEL, Distrito Federal. Instituto Central de Ciências (ICC) Norte, Gleba A, Campus Universitário Darcy Ribeiro, Asa Norte, 70904-970, Brasília, DF, Brasil.

barcellos.vicente@gmail.com 
mações econômicas e sociais, que fez com que o Estado se tornasse importante polo de produção de grãos, impulsionando rápidas transformações na antiga rede de cidades, até então concentrada nas terras baixas da parte sul do Estado.

O presente trabalho é composto de três partes. A primeira trata dos processos de colonização que fazem avançar a fronteira agrícola e estabelecem os povoados que, posteriormente, se transformariam nas novas cidades. A segunda parte traz considerações sobre as antigas cidades de Mato Grosso, com o objetivo de estabelecer um contraponto com as novas cidades. A última parte inclui breves observações sobre as sete novas cidades aqui consideradas: Sinop, Sorriso, Lucas do Rio Verde, Nova Mutum, Campo Novo do Parecis, Campo Verde e Primavera do Leste.

Assim, buscamos fazer uma primeira aproximação com a problemática dessas novas cidades - por considerar que têm recebido pouca atenção do meio acadêmico, embora a produção agrícola das regiões onde se inserem ganhe cada vez mais importância para o país.

Com as sucintas notas aqui reunidas sobre as sete cidades, esperamos contribuir para a reflexão sobre os processos que as geraram, bem como ajudar a pensar os modos como a esfera pública vem sendo constituída nesses novos contextos, e como ela tem contribuído para a organização das referidas paisagens urbanas, nos seus mais precípuos elementos organizadores: os espaços livres públicos, ou seja, nos seus sistemas de ruas, avenidas, praças e parques. Entretanto, para que possamos entender essas novas cidades, antes de tudo é preciso entender os processos que as fizeram surgir.

\section{O AVANÇO DA FRONTEIRA AGRÍCOLA E DA REDE DE CIDADES}

A rede de cidades nos domínios do cerrado, a partir da década de 1970, em especial a rede urbana de Mato Grosso, passa por intenso crescimento, resultado das políticas públicas de estímulo à colonização agrária adotadas no regime militar. Tais políticas tinham como foco a ocupação de terras consideradas pouco ocupadas, realizada por meio da colonização agrária, e se coadunavam com a ideologia de segurança nacional, ao mesmo tempo em que objetivavam atender as demandas por terras - tanto as originárias de populações do Nordeste e do Sul do país - como modo de desmobilizar conflitos que se acirravam no campo'.

A ideologia desenvolvimentista e a ideia de "Marcha para o Oeste" são fundidas no Programa de Integração Nacional, que toma como um dos seus principais objetivos a colonização agrária no arco que envolve a Amazônia². Para isso foram abertas rodovias, concedidos incentivos fiscais, e pesquisas foram estimuladas como meio de superar obstáculos colocados pelo clima e pelo solo pobre e ácido do cerrado.

Esses processos de colonização seguiram duas linhas distintas. A primeira tem como marca a intervenção direta do Instituto Nacional de Colonização e Reforma Agrária (Incra), que parcelava e distribuía lotes rurais a migrantes, principalmente do Nordes-

\footnotetext{
Bernardes (2007)

$\operatorname{Becker}$ (1988, p. 69).
} 
te. A atual ocupação do interior de Rondônia, bem como o surgimento de muitas das suas atuais cidades, são resultados dessas intervenções estatais ${ }^{3}$. A segunda linha de colonização, embora também decorrente de estímulo do poder público, teve como principal ator a iniciativa privada.

Essa solução predominou em Mato Grosso e no oeste da Bahia. Os excedentes de população rural do sul do país, em geral pequenos e médios agricultores que dispunham de recursos e de energia para migrar, acabaram por constituir os principais clientes da colonização privada.

Os principais fatores de atração de tal clientela eram o baixo custo e a abundância das terras, fato que contrastava com o alto custo e a exiguidade de terras encontradas no sul do país. $\bigcirc$ inconveniente eram o isolamento e a ausência de qualquer infraestrutura de apoio, seja em termos de estradas, seja pela própria ausência de núcleos urbanos de apoio em que fosse possível buscar serviços de saúde, educação ou o simples abastecimento. Agravava a situação o desconhecimento das técnicas de manejo dos pobres e ácidos solos do cerrado, motivo pelo qual essas regiões tinham, até então, permanecido quase intocadas.

$\mathrm{Se}$, inicialmente, os primeiros colonizadores - em sua maioria de pequenas posses, que plantavam usando um mínimo de técnicas modernas - conseguiam algum sucesso, logo esses bons resultados atraíam novos colonos, com maior disponibilidade de capital para aquisição de maiores quantidades de terra e disponibilidades de tecnologia.

Nesse processo, o colono que dispunha de maior preparo técnico e maior quantidade de crédito e capital acumulado teve maior possibilidade de passar para uma escala de produção economicamente mais viável, enquanto outros acabaram desistindo e se desfazendo de suas propriedades, em muitos casos para investidores que não participaram das árduas etapas iniciais de colonização.

Fator decisivo para a consolidação desse processo de colonização e ocupação foi o desenvolvimento e a disseminação de novas tecnologias agrícolas, que permitiram vencer empecilhos que, até então, dificultavam a produção nos domínios do cerrado. Nesse sentido, a pesquisa pública realizada pela Empresa Brasileira de Pesquisa Agropecuária (Embrapa) foi decisiva, pois, além de desenvolver tecnologias de manejo dos solos, criou variedades de grãos adaptados às peculiares condições do cerrado. Foi a partir daí que se desenvolveu uma indústria que passou a fornecer novos meios e materiais para produção agrícola.

Resolvidos os entraves técnicos à produção agrícola, os colonos se mostraram capazes de absorver as novas tecnologias, e, pouco a pouco, passaram a desenvolver nas terras planas do alto das chapadas uma agricultura que induzia o trato mecanizado do solo e o aumento das escalas de produção. Nesse processo, a intensificação do uso de tecnologias viabilizou constantes aumentos de produtividade, e acabou por contribuir para que, ano a ano, o país viesse apresentando constantes aumentos das safras produzidas.

3 Coy (1988). 
Hoje, a fronteira agrícola está consolidada e a produção cada vez ganha mais importância na economia nacional ${ }^{4}$. Há uma cadeia produtiva de soja, algodão, milho, feiião, sorgo e outros grãos, que tanto atende as demandas da indústria nacional de alimentos e de rações, como produz excedentes para exportação - destacando-se as produções de soja e milho, que têm ajudado nos superávits da balança comercial brasileira. Além de produzir excedentes para exportação, a agricultura brasileira tem atendido as demandas internas de alimentos, num contexto de constantes aumentos do consumo, principalmente pela emergência da chamada nova classe média ${ }^{5}$.

Essa modernização da produção agrícola só se fez possível com o surgimento de cidades de apoio à produção do campo, pois são nas cidades que se concentram os trabalhadores necessários à sua realização, os serviços técnicos e as agroindústrias. As cidades, nesses casos, não podem ser entendidas como simples locais de moradia de boias-frias.

Os dados de população dos municípios envolvidos na produção de grãos em Mato Grosso, segundo Bernardes (2007), permitem dizer que a superioridade da população urbana em relação à rural é reveladora da importância do espaço urbano nas atividades agrícolas modernas, e que algumas das características do trabalho nesses municípios são: o vínculo empregatício com carteira assinada, o reduzido número de analfabetos e o significativo número de trabalhadores com nível superior de escolaridade.

Uma das principais características da distribuição das antigas cidades de Mato Grosso é sua localização junto aos rios que fazem parte da bacia do rio Paraguai. Nas altas e planas chapadas situadas ao norte - integrando, portanto, a bacia do Amazonas, cujas terras foram escolhidas para colonização - havia um vazio de cidades.

De fato, a rede de cidades de Mato Grosso até a divisão do Estado e a criação do Mato Grosso do Sul, nos idos de 1979, era bastante incipiente. E a situação pouco foi alterada até os processos de colonização que fizeram avançar a fronteira agrícola.

A chegada de imigrantes vindos do sul - contingente constituído de pequenos sitiantes, principalmente gaúchos e paranaenses, que imigravam atraídos pela fartura de terras vendidas a preços relativamente baixos pelas empresas de colonização agrária - fez surgir os primeiros núcleos populacionais. Em muitos casos, esses núcleos surgiram de modo improvisado, como meio de apoio às necessidades imediatas de bens e serviços das populações que chegavam para se instalar no campo.

Em outros casos, pequenos núcleos de apoio, de características urbanas, foram abertos como atrativos suplementares aos colonos: ao adquirirem terras para produção, adquiriam o direito a um lote no núcleo de apoio. $\bigcirc$ estabelecimento desses núcleos de apoio, em muitos casos, mostrou-se vantajoso, pois nem todos os imigrantes que vinham em busca de oportunidades tinham recursos, condições ou interesse nas atividades do campo.

Segundo Guanziroli (2006), o agronegócio, entendido como a soma dos setores produtivos com os de processamento do produto final e os de fabricação de insumos, responde por quase um terço do Produto Interno Bruto (PIB) do Brasil, e por valor semelhante das exportações totais do país, sendo a soja uma das principais responsáveis por boa parte dos superávits comerciais e das reservas acumuladas em moeda estrangeira.

5 Sobre a emergência da "nova classe média" ver Neri (2010). 
O desenvolvimento de novas técnicas de produção agrícola no cerrado foi fator primordial para a consolidação e o desenvolvimento da região. Mas tal não teria sido possível sem a transformação daqueles pequenos núcleos urbanos iniciais em cidades, que, mais adiante, se tornariam sedes municipais.

Os processos de transformação que fizeram com que Mato Grosso se tornasse um dos principais polos de produção de grãos do país não parecem terminados ${ }^{6}$. Até mesmo porque os fatores que colocam em marcha esses processos são internos, como os resultantes das mudanças sociais, mas, também, exógenos - já que parte da produção destina-se ao atendimento das demandas mundiais.

Desde a década de 1990, a produção de grãos brasileira vem passando por constantes aumentos para atender as demandas, fato que sugere que as cidades na região vêm mantendo o expressivo crescimento que apresentam e se consolidando como centros de dinamismo econômico e social.

Evidentemente, não foram poucos os custos sociais e ambientais desse processo de colonização. Não obstante a gravidade desses passivos, eles não são objeto do presente trabalho, que tem como foco as seguintes novas cidades: Sinop, Sorriso, Lucas do Rio Verde, Nova Mutum, Campo Novo do Parecis, Campo Verde e Primavera do Leste (figura 1).

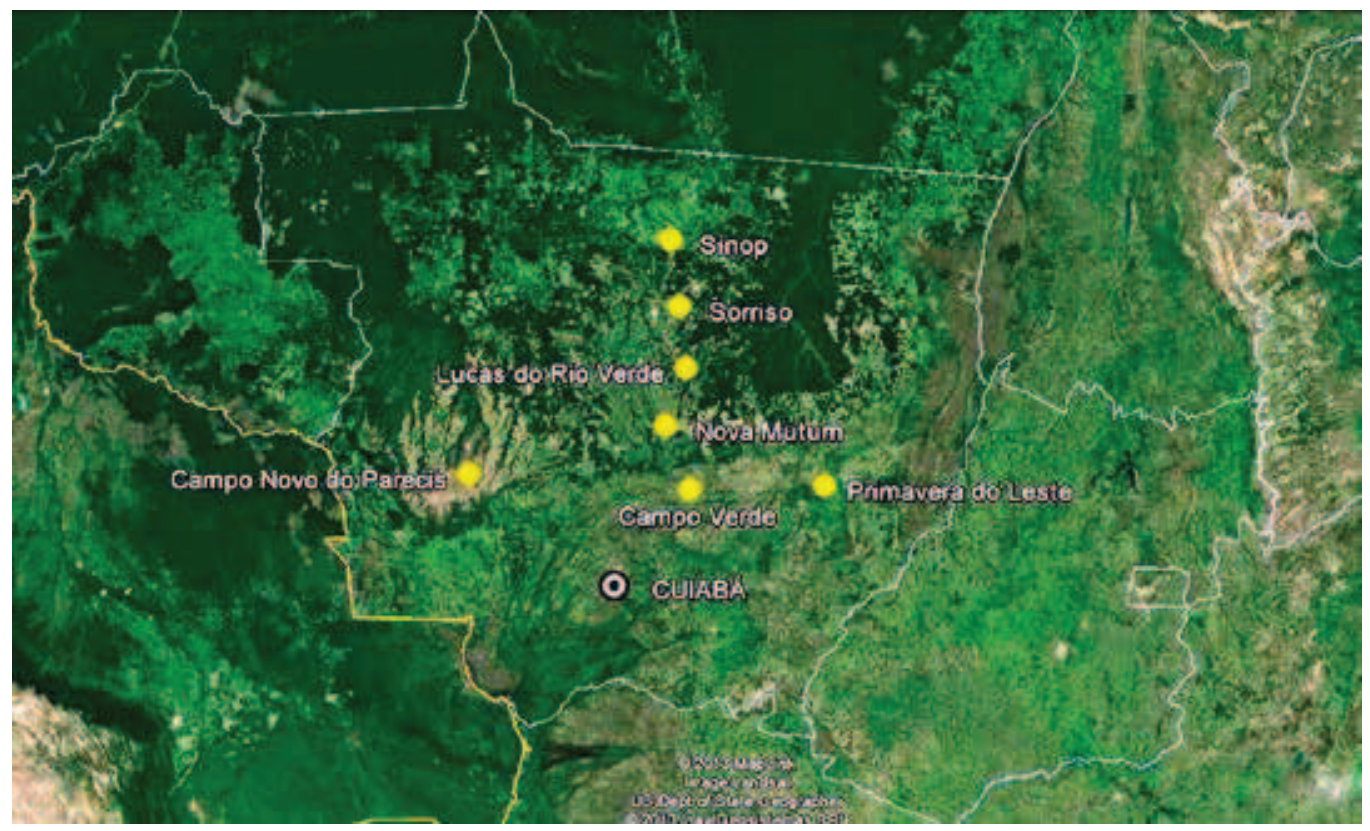

Figura 1 As novas cidades de Mato Grosso (em amarelo), surgidas na década de 1970, e as antigas cidades (em branco).

Fonte: Google Earth. Acesso em: 17 jul. 2010.

6 Como evidência do peso da contribuição de Mato Grosso nas exportações brasileiras, vale mencionar que, em 2009, o Estado se tornou o maior exportador de soja, ultrapassando o Rio Grande do Sul, que, até então, liderava. Do mesmo modo, superou o Paraná como maior exportador de milho (BATISTA, Fabiana; BOTELHO, Gilmara. Soja ajuda MT a superar PR e RS em exportações. Gazeta Mercantil, Brasília, 23 abr. 2009, Agronegócio, p. B10. Disponível em: <http://www2.senado.gov.br/bdsf/item/id/491263>. 
Para que se tenha ideia do estágio de desenvolvimento econômico e social dessas cidades, apresentamos o Quadro 1.

Quadro 1 Dados Gerais de Algumas das Novas Cidades de Mato Grosso

\begin{tabular}{l|c|c|c|c}
\hline Município & $\begin{array}{c}\text { Ano de } \\
\text { Emancipação }\end{array}$ & $\begin{array}{c}\text { População } \\
\text { Censo 2010 }\end{array}$ & $\begin{array}{c}\text { PIB per capta } \\
\text { em reais }\end{array}$ & $\begin{array}{c}\text { IDH 2000 } \\
* * *\end{array}$ \\
\hline Sinop & 1979 & 113.009 & $17.787,12$ & 0.807 \\
\hline Sorriso & 1987 & 66.521 & $31.081,96$ & 0.824 \\
\hline Lucas do Rio Verde & 1988 & 45.556 & $36.269,32$ & 0.818 \\
\hline Nova Mutum & 1988 & 31.649 & $45.078,60$ & 0.801 \\
\hline Campo Novo do Parecis & 1988 & 27.577 & $41.564,63$ & 0.809 \\
\hline Campo Verde & 1988 & 31.589 & $34.639,94$ & 0.800 \\
\hline Primavera do Leste & 1986 & 52.066 & $39.778,94$ & 0.805 \\
\hline
\end{tabular}

*Censo 2010. Disponível em: <http://www.ibge.gov.br/cidadesat/index.php>.

Acesso em: 12 dez. 2013. **Em preços correntes. Disponível em: <http://www.ibge.gov.br/cidadesat/index.php>.

Acesso em: 12 dez. 2013. *** IDH - Índice de Desenvolvimento Humano com base nos dados do Censo 2000.

Fonte: Programa das Nações Unidas para o Desenvolvimento(PNUD).

Disponível em <http://www.pnud.org.br/IDH/DH.aspx>. Acesso em: 28 jul. 2013.

As novas cidades de Mato Grosso contrastam bastante com as antigas cidades, que não estão diretamente envolvidas na moderna agricultura praticada no Estado, exceção de Cuiabá e Rondonópolis, a segunda maior cidade (195.476 habitantes), considerada capital regional e polo do agronegócio. As demais antigas cidades apresentam certa estagnação do crescimento da população e indicadores socioeconômicos incomparavelmente inferiores aos das novas cidades.

Tal é o caso de Acorizal, município emancipado em 1953, que, no Censo de 2010, aparece com 5.516 habitantes (IBGE). Acorizal apresenta Produto Interno Bruto (PIB) per capta de R\$9.402,667 e Índice de Desenvolvimento Humano de 0,695 - considerado médio pelo Programa das Nações Unidas para o Desenvolvimento (PNDU, 2010).

O município de Poxoréo, emancipado em 1938, hoje com 17.599 habitantes (Censo IBGE, 2010), apresenta PIB per capta de R $\$ 15.749^{8}$ e IDH de 0,743 (PNUD, 2010) valor também considerado médio.

Essas diferenças nos indicadores entre as novas e as antigas cidades evidenciam o alheamento destas aos novos fluxos econômicos e sociais resultantes da moderna produção agrícola, fato que pode ser explicado pela sua localização - nos sopés das chapadas, em locais pouco integrados às áreas da moderna produção agrícola.

Em preços correntes. Fonte: IBGE. Disponível em: <http://www.ibge.gov.br/cidadesat/index.php>. Acesso em: 12 dez. 2013

8 Em preços correntes. Fonte IBGE. Disponível em: <http://www.ibge.gov.br/cidadesat/index.php>. Acesso em: 12 dez. 2013. 


\section{NOVAS PAISAGENS URBANAS DE MATO GROSSO}

Antes de tudo, é preciso deixar claro que a expressão "novas paisagens urbanas" refere-se às cidades resultantes dos processos de colonização e de avanço da fronteira agrícola iniciados na década de 1970. Evidentemente, o número de novas cidades surgidas desde então ultrapassa em muito o número de cidades examinadas a seguir.

Entretanto, dentro das limitações do presente trabalho, escolhemos fazer algumas considerações sobre sete dessas novas cidades, que entendemos como mais significativas -, por sua vinculação econômica, social e cultural à moderna agricultura que se instalou no Estado.

As cidades analisadas podem ser divididas em três partes. A primeira parte, distribuída ao longo da BR-163 (liga Cuiabá à Santarém, no Pará), inclui Sinop, Sorriso, Lucas do Rio Verde, Nova Mutum. A segunda parte se restringe à cidade de Campo Novo do Parecis, situada no oeste do Estado, na chapada do Parecis. A terceira parte inclui as cidades de Campo Verde e Primavera do Leste, situadas na chapada dos Guimarães, próximas à Rondonópolis, a segunda cidade do Estado.

\section{SINOP}

Sinop é a maior e a mais antiga das novas cidades, e, ao contrário das demais aqui estudadas, situa-se inteiramente no bioma amazônico, fato que talvez explique a maior vinculação do município à economia da madeira, e menor à produção de grãos. É popularmente conhecida como a "Capital do Nortão", por ter, em sua área de influência, extensas áreas e inúmeras novas cidades, situadas no extremo norte do Estado.

O surgimento de Sinop é resultante dos processos de colonização empreendidos pela Sociedade Imobiliária Noroeste do Paraná (Sinop, daí o nome da cidade), responsável, também, pelo surgimento de outras cidades-sedes de municípios das proximidades, como Vera, Santa Carmem e Cláudia.

Na verdade, o que a referida empresa realiza em Mato Grosso é repetir, em maior escala, a experiência de colonização adquirida no oeste do Paraná, cujo processo consistia na criação de um núcleo urbano de apoio envolvido por um cinturão verde de chácaras e lotes rurais de maiores dimensões, situação que remete às concepções de cidade-jardim de Ebenezer Howard?.

O traçado da cidade de Sinop organiza-se no sistema de tabuleiro que combina largas avenidas com canteiros centrais, cujas caixas de rua situam-se entre 30 e 40 metros, e ruas, que, em sua maioria, apresentam caixas de 20 metros - situação bastante favorável, com calçadas bastante generosas. No encontro das avenidas, há praças rotatórias: algumas com pequeno diâmetro, outras com grande, que chegam a produzir caixas de rua atingindo 130 metros de largura.

Referimo-nos às cidades de Terra Rica, Iporã, Ubiratã, Formosa do Oeste, Jesuítas e vários povoados que não atingiram a condição de cidades. 
As condições de tratamento e manutenção das ruas são bastante razoáveis. A maior parte delas se apresenta pavimentada, com drenagem pluvial, e, em menor escala, arborizada. Entretanto, as condições de tratamento e manutenção dos espaços livres públicos da cidade podem ser consideradas inferiores às demais cidades estudadas aqui, em especial, se comparadas a Lucas do Rio Verde.

Um aspecto que chama atenção em Sinop é a existência de um parque de grandes dimensões que é envolvido pela cidade - na verdade, um parque florestal que engloba Áreas de Preservação Permanente (APP), aberto ao acesso do público (figura 2).

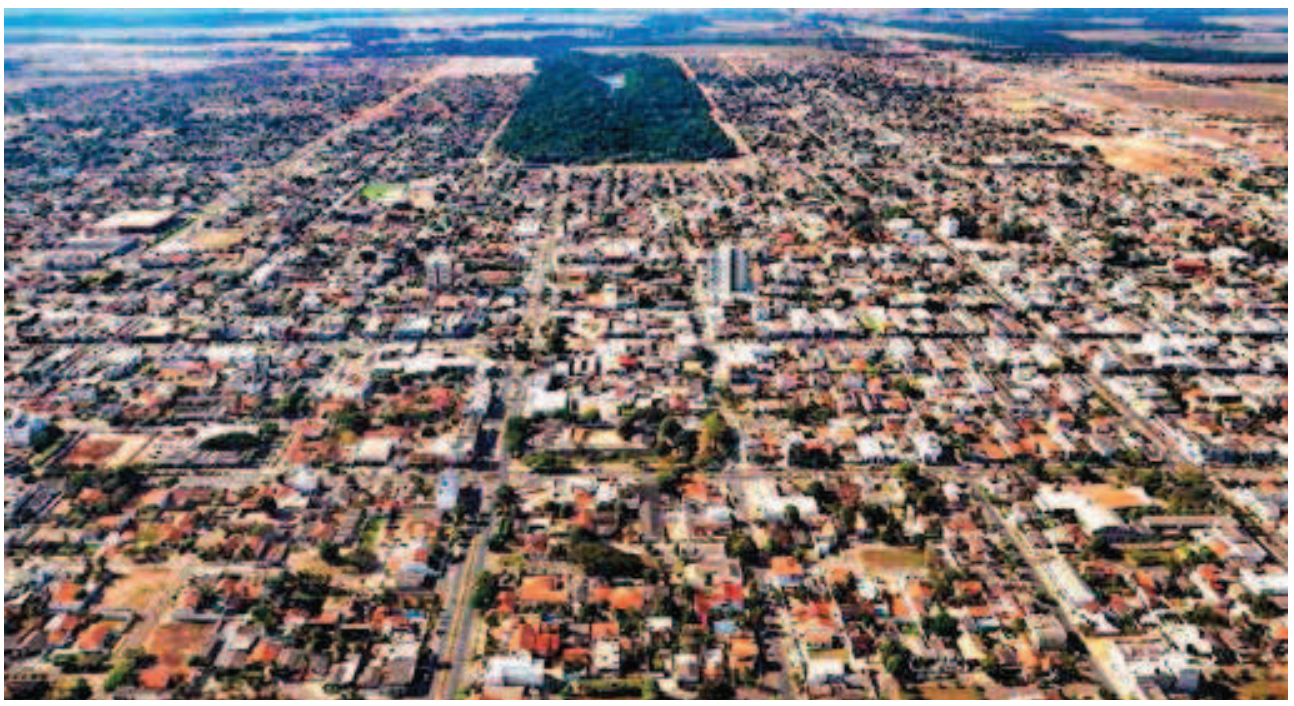

Figura 2 Vista aérea de Sinop. No primeiro plano, o centro da cidade; no fundo, o Parque Florestal - 2013. Fonte: Prefeitura Municipal de Sinop.

\section{SORRISO}

Sorriso situa-se às margens da BR-163, área de transição da Amazônia para o cerrado. O município está diretamente relacionado ao agronegócio, sendo um dos maiores produtores de soja do país, além de apresentar produções de milho e algodão, situação que atraiu para o município grandes empresas nacionais e estrangeiras.

Algumas aproveitam esses recursos na produção e industrialização de carne de frango e de suínos. $O$ surgimento da cidade se deve à Colonizadora Feliz, empresa que até hoje atua na cidade, embora já tenha perdido a hegemonia dos processos de loteamento urbano. A maior parte dos lotes urbanos foi vendida a colonos vindos do sul do país.

Tal como em Sinop, as ruas e avenidas de Sorriso obedecem ao sistema de tabuleiro, embora as caixas das vias tenham menores dimensões, e as praças rotatórias só residualmente estão presentes. Ainda assim, apresentam dimensionamento satisfatório (figura 3). A cidade dispõe, na área central, de um parque bem tratado, com boa infraestrutura de lazer e recreação, bem como um sistema de praças - a maioria apresentando boas condições de uso pela população. 
Nas áreas periféricas em processo de ocupação, ainda com grandes vazios, há muitas ruas e avenidas sem pavimentação e com precária infraestrutura urbana, sem condições de receber a população que chega para se estabelecer.

Mesmo assim, podemos dizer que o conjunto de espaços livres públicos de Sorriso apresenta boas condições de tratamento e manutenção, e sua paisagem urbana, tal como nas demais novas cidades consideradas, apresenta características que a distinguem da maior parte das cidades do interior brasileiro, resultado do estágio de desenvolvimento econômico e social alcançado por elas (figura 4).

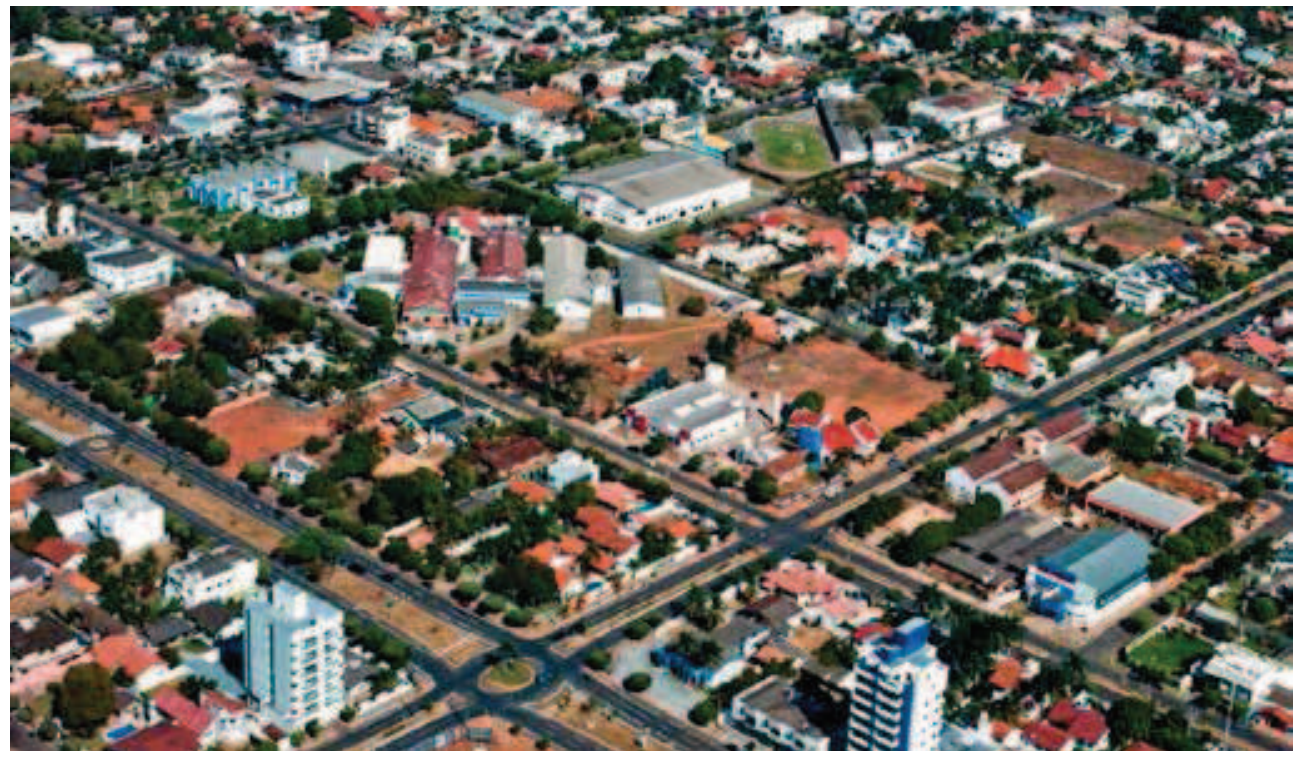

Figura 3 Vista aérea de uma das avenidas de Sorriso - 2013. Fonte: Prefeitura Municipal de Sorriso.

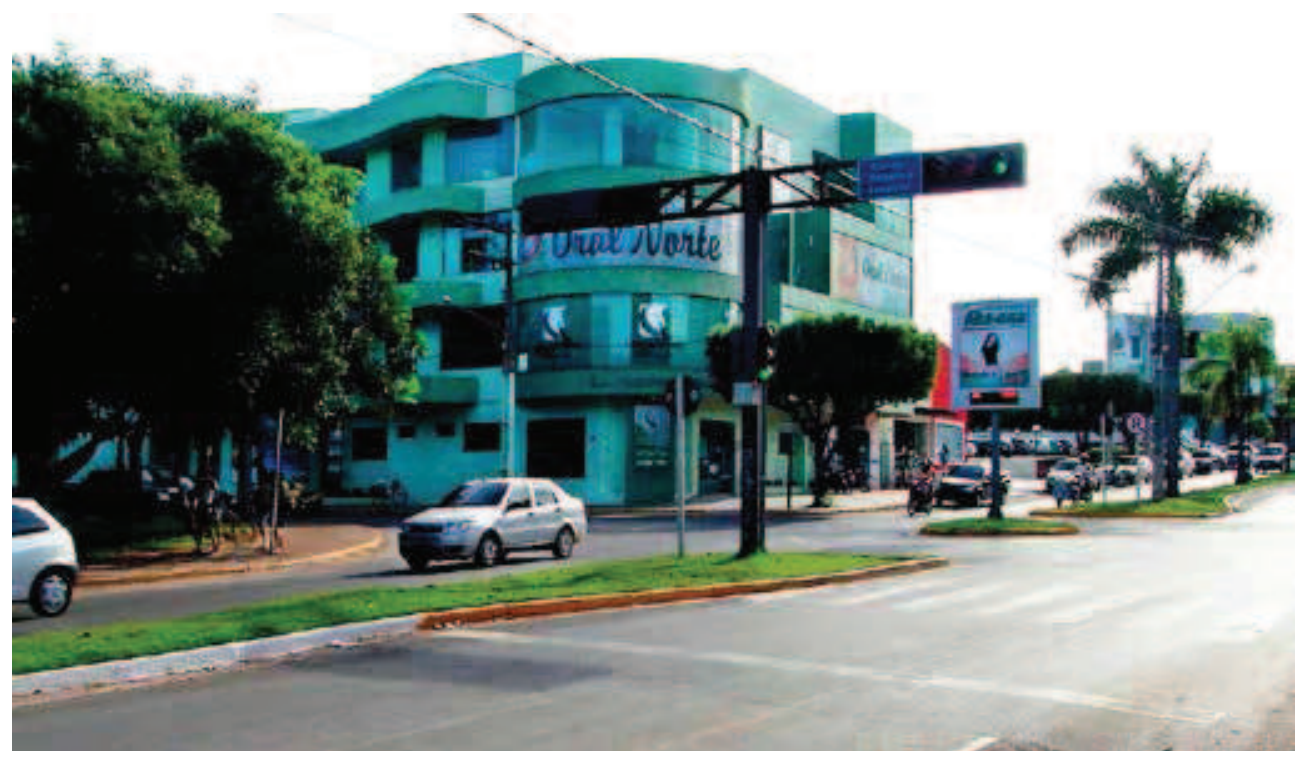

Figura 4 Avenida da área central de Sorriso.

Foto: Vicente Barcellos - 2010. 


\section{LUCAS DO RIO VERDE}

Lucas do Rio Verde se distingue dos demais municípios situados ao norte de Mato Grosso por dois motivos: o primeiro, por estar situado, segundo o IBGE, no bioma cerrado; o segundo, por sua colonização não poder ser atribuída à iniciativa privada.

Os primeiros imigrantes chegaram ao local em 1977, quando da abertura da BR163 - mas só em 1981 o INCRA iniciou a colonização. O projeto de urbanização da cidade data de 1986, e foi feito por técnicos do referido órgão, que abriu as primeiras ruas em terra e marcou os lotes.

A cidade é, hoje, um dos principais polos do agronegócio do país. A atual paisagem urbana de Lucas do Rio Verde é fruto de sua evolução, que pode ser descrita em três fases (figura 5).

A primeira ocorreu com a implantação do projeto de arruamento do INCRA, que ocupou as áreas situadas entre a BR-163 e o córrego Lucas, em cujo entorno foi criado o principal parque da cidade; a segunda, com a implantação do loteamento situado além do córrego; a terceira, com a ocupação do lado oeste da BR-163, ao longo da qual, inicialmente, só havia instalações agroindustriais (área que, depois, sofreu diversas expansões); a última fase de evolução ocorreu com a adição do uso residencial e de serviços, situação que gerou conflitos $^{10}$.

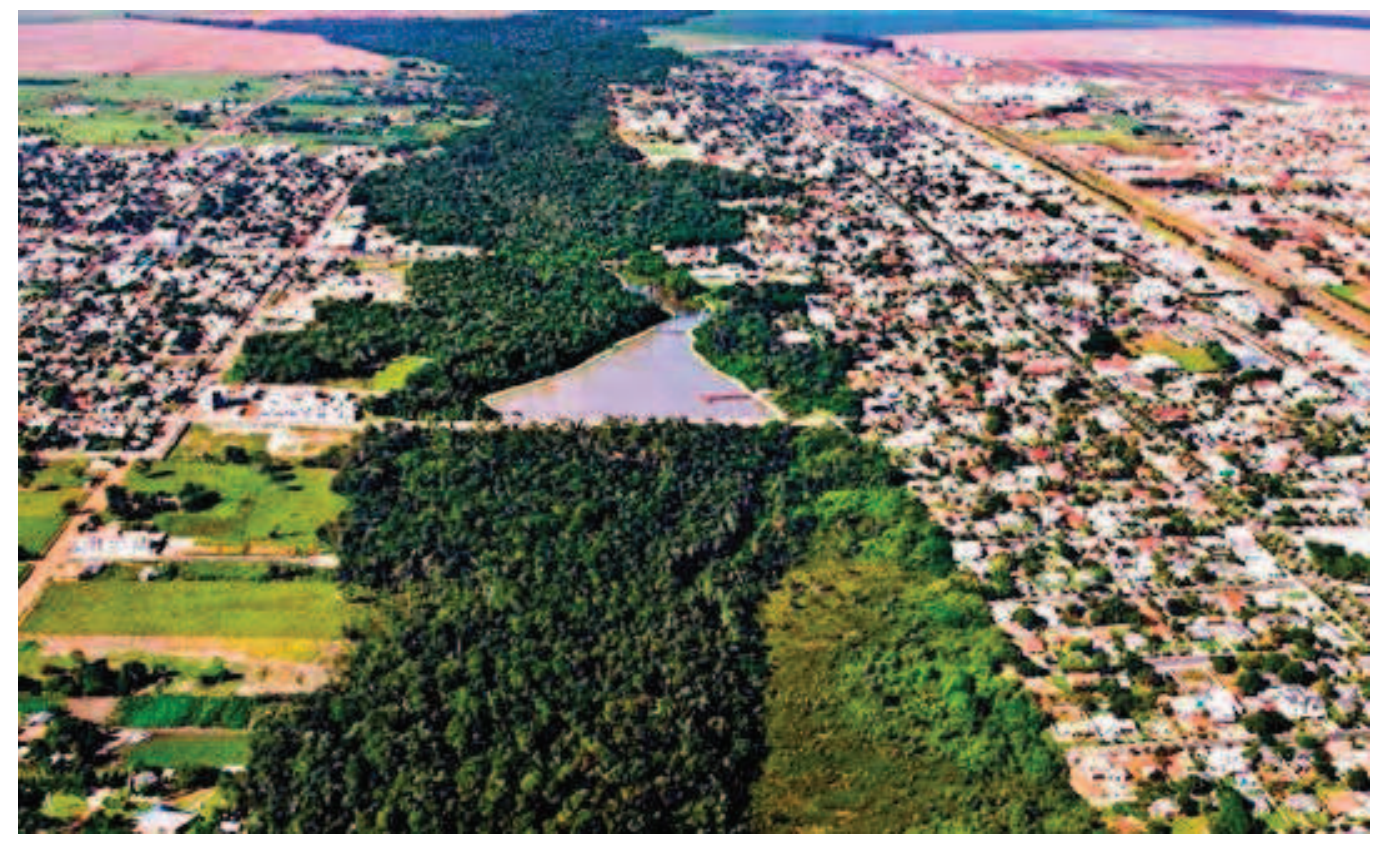

Figura 5 Vista aérea de Lucas do Rio Verde - 2013. À esquerda do parque tem-se a segunda fase de expansão urbana. Entre o parque e a BR-163, situa-se a área mais consolidada da cidade (projetada pelo INCRA). Do lado direito, depois da rodovia, situa-se a terceira fase de ocupação.

Fonte: Prefeitura Municipal de Lucas do Rio Verde.

10 Ver o Plano Diretor de Lucas do Rio Verde - Prefeitura Municipal de Lucas do Rio Verde (2007). 
O sistema de espaços livres públicos da cidade é satisfatório, principalmente, se comparado com a maioria das cidades brasileiras. As caixas das ruas e das avenidas variam de 20 a 40 metros de largura, e, de modo geral, apresentam muito boas condições de tratamento e manutenção. As vias mais largas apresentam ilhas ou canteiros centrais separando as duas pistas.

O dimensionamento de tais canteiros centrais é muito variado, em alguns casos chega a 10 metros de largura. Esse bom dimensionamento das ruas e avenidas permitiu a implantação de um sistema de ciclovias que percorre a maior parte da cidade (figuras 6 e 7).

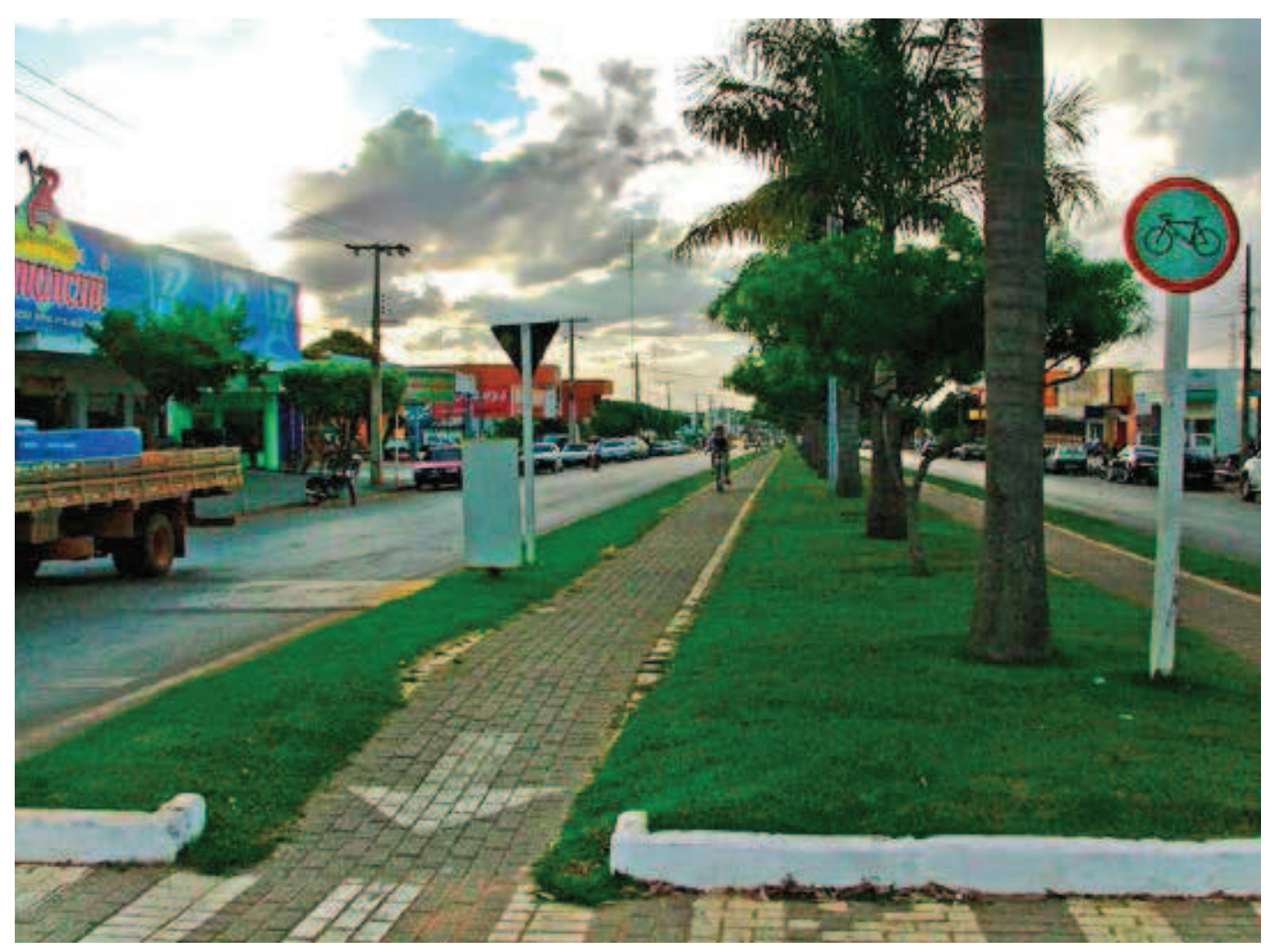

Figura 6 Ciclovia situada em canteiro central de avenida no bairro Cidade Nova. Foto: Vicente Barcellos - 2010.

Chama atenção a preocupação com o ajardinamento e a arborização urbana. Evidentemente, nas partes mais antigas da cidade, as árvores já estão mais maduras e propiciam bom sombreamento - enquanto nas partes novas não cumprem ainda esse papel. Mesmo nas áreas de expansão urbana, cuja infraestrutura está em construção, à medida que as obras vão sendo terminadas, vão sendo, também, secundadas pela arborização de ruas e avenidas.

A cidade dispõe de um conjunto de praças razoavelmente organizado e bem distribuído. O maior e principal parque da cidade é uma extensa faixa de APP que envolve o córrego Lucas e suas matas ciliares e cuja largura varia entre 200 e 400 metros, 
separando a parte mais consolidada e central da cidade do bairro Cidade Nova, da segunda fase de expansão urbana.

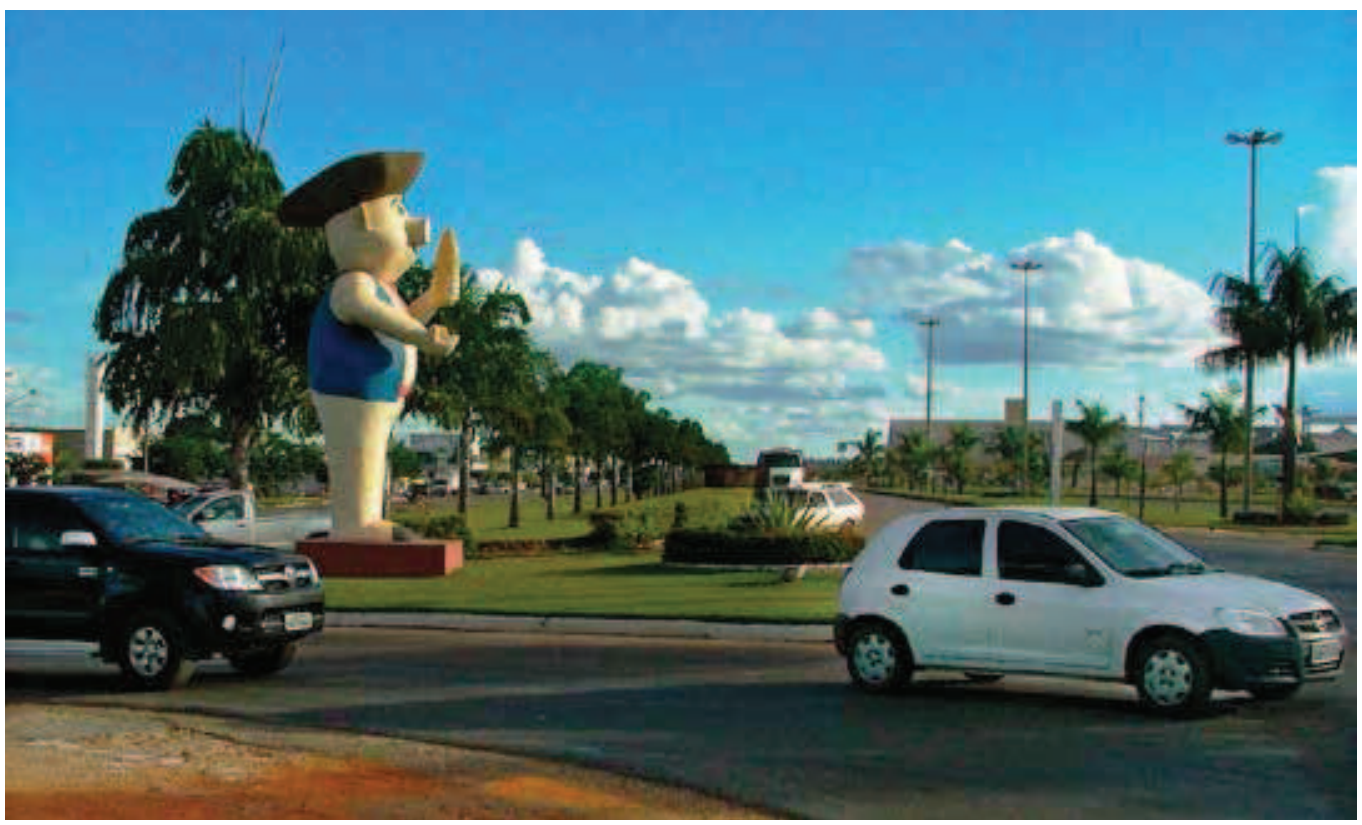

Figura 7 Acesso a Lucas do Rio Verde, pontuado pela escultura de um porco com uma espiga de milho na mão, às margens da BR-163.

Foto: Vicente Barcellos - 2010.

\section{NOVA MUTUM}

O município de Nova Mutum tem como antecedente um projeto de pecuária da empresa Mutum Agropecuária S/A, que, inicialmente, atuava apenas na criação e engorda de gado - e que, diante do afluxo de colonos que passam pela região em direção a Lucas do Rio Verde e outras áreas de colonização, resolve, em 1977, iniciar seu próprio projeto de colonização.

Para começar, a colonizadora construiu dez casas numa vila aberta provisoriamente utilizando trator de esteira. Em seguida, uma escola, um centro comunitário, um posto de saúde e alojamento para abrigar os compradores de terra, infraestrutura considerada essencial para que o projeto de colonização pudesse iniciar. Para o centro urbano foram reservados 551 hectares, e quem adquirisse um lote rural, recebia como bonificação dois terrenos urbanos.

Na fase inicial, a empresa se responsabilizou pela administração do núcleo urbano, inclusive pela contratação de médicos e enfermeiras. Embora Nova Mutum tenha ganhado status de distrito do município de Diamantino já em 1981, é só mais adiante, em 1988, que a cidade ganha um posto telefônico. A cidade se desenvolve ao longo da rodovia BR-163, cujas laterais são ocupadas por silos de armazenagem de grãos, abatedouros de frango e suínos e estabelecimentos de serviços ligados à produção agrícola e ao transporte. 
Perpendicularmente à rodovia, largas avenidas, que chegam a quase 50 metros de largura, organizam o sistema em tabuleiro com grandes praças rotatórias. $E$, tal como nas cidades anteriormente examinadas, o tabuleiro é interrompido por extensa APP, que, no caso, apresenta-se degradada e sem benfeitorias que possibilitem o uso público sob a forma de parque (figuras 8 e 9).

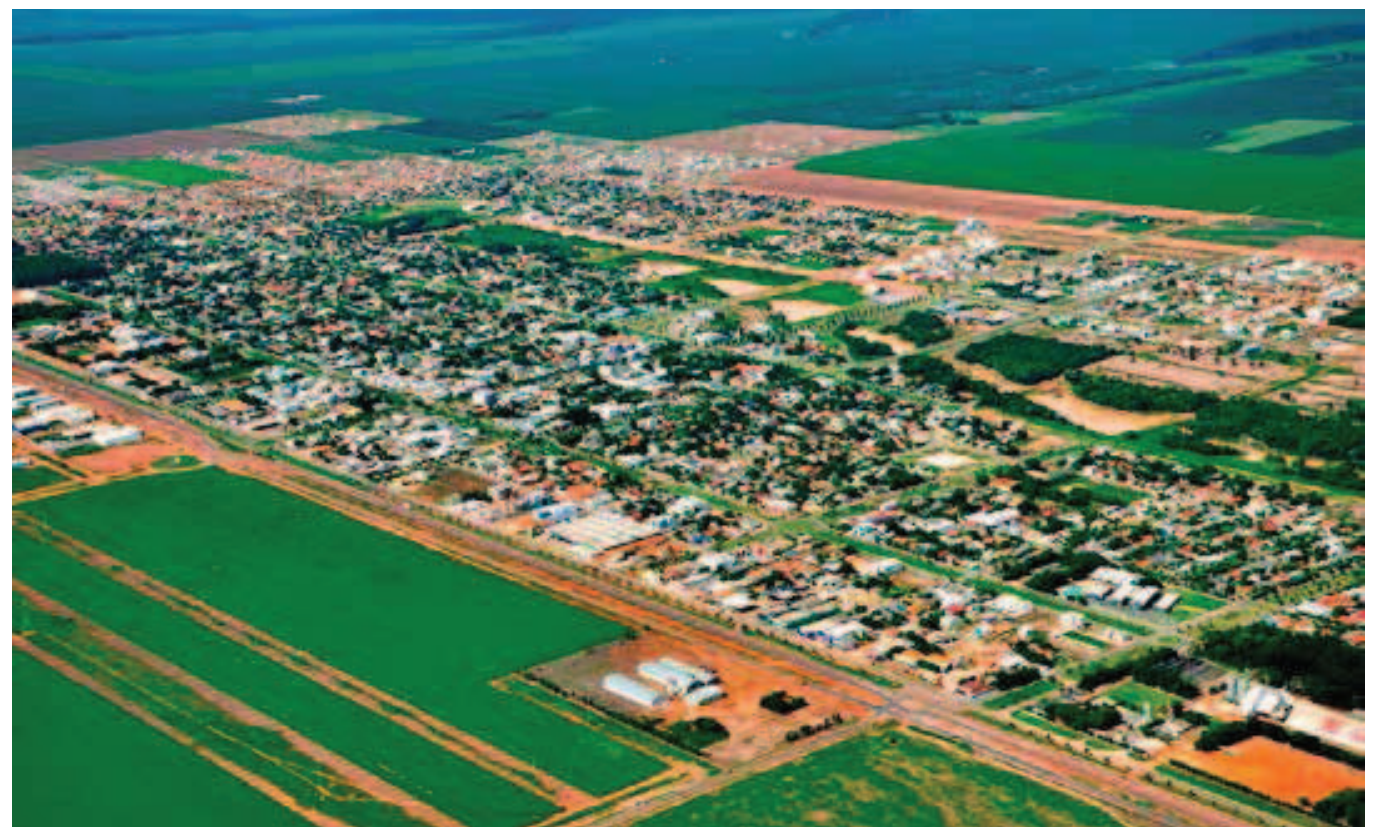

Figura 8 Vista aérea de Nova Mutum - 2013.

Fonte: Prefeitura Municipal de Nova Mutum.

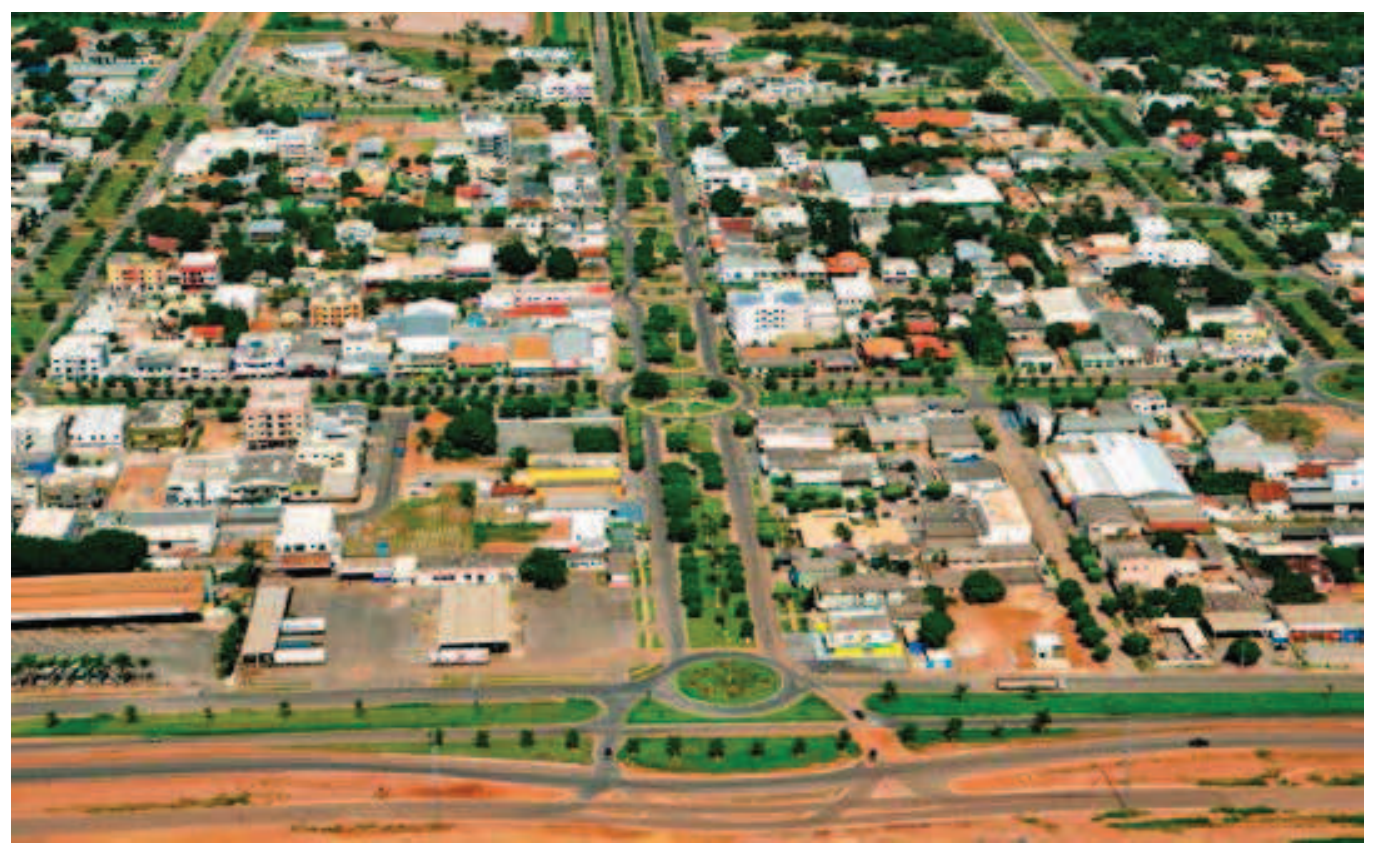

Figura 9 Vista aérea de Nova Mutum, tendo, no primeiro plano, a BR-163 - 2013.

Fonte: Prefeitura Municipal de Nova Mutum. 
Embora a emancipação do município tenha ocorrido em 1988, portanto, na mesma época das demais cidades, a aceleração do desenvolvimento de Nova Mutum ocorreu apenas nos últimos anos, quando aportaram no município grandes investimentos do agronegócio, fato que explica a aceleração recente do volume de construções na cidade e a própria expansão da ocupação urbana.

Assim, é compreensível que os espaços livres públicos das partes mais consolidadas da cidade estejam mais organizados, enquanto nas partes em processo de ocupação tudo esteja por fazer (figura 10).

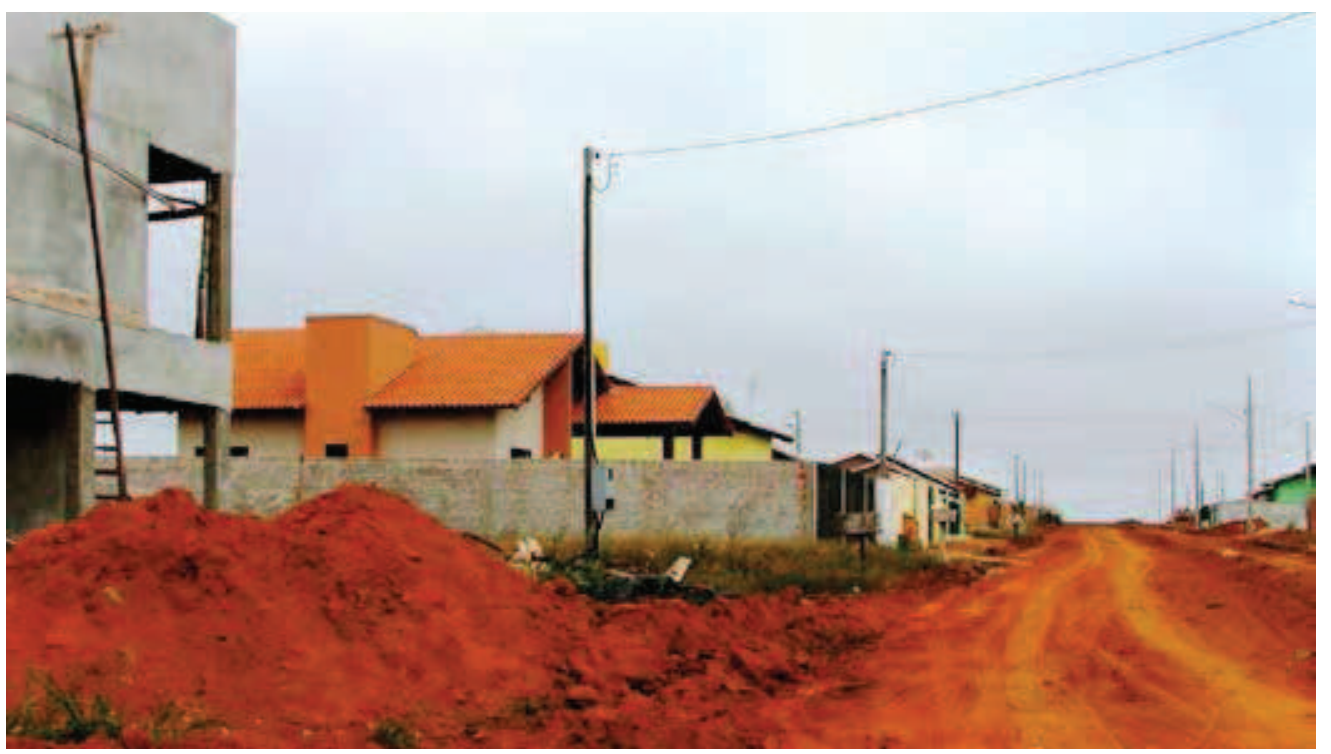

Figura 10 Nova Mutum. Expansão de bairro residencial. Foto: Vicente Barcellos - 2010.

\section{CAMPO NOVO DO PARECIS}

Embora seu território tenha sido trabalhado pelo Marechal Cândido Rondon, quando do estabelecimento das linhas telegráficas no início do século XX, foi na década de 1970, com a abertura de fazendas e a instalação de famílias de imigrantes vindos do sul, às margens de um cotovelo da estrada que ligava Diamantino e Utiariti, que surgiu o povoado que deu origem a cidade. Com a criação do município, em 1988, passou a chamar-se Campo Novo do Parecis.

O crescimento e a consolidação de Campo Novo do Parecis parecem ter sido retardados, se comparado às demais cidades estudadas. Entretanto, a cidade é fruto dos mesmos processos de colonização privada adotados em outros cantos do Estado. Ou seja, os lotes rurais se concentram no entorno do núcleo urbano - que tem seu crescimento assegurado pela distribuição de um lote urbano para cada aquisição de lote rural, solução que dá ênfase à cidade.

O traçado de Campo Novo do Parecis pouco difere das demais cidades, a não ser pelo fato de, durante a sua evolução, ter ocorrido certo nível de descontinuidade do 
tecido urbano, que distancia bairros periféricos de recente ocupação das áreas centrais e mais consolidadas da cidade (figura 11).

Embora as áreas periféricas da cidade que estão em processo de expansão apresentem muitos problemas por resolver, a área central apresenta bom nível de organização da paisagem urbana, fato que fica evidente no bom tratamento de ruas e avenidas, na oferta de equipamentos públicos de saúde e de ensino, bem como no respeito da população às faixas de pedestres (figura 12).

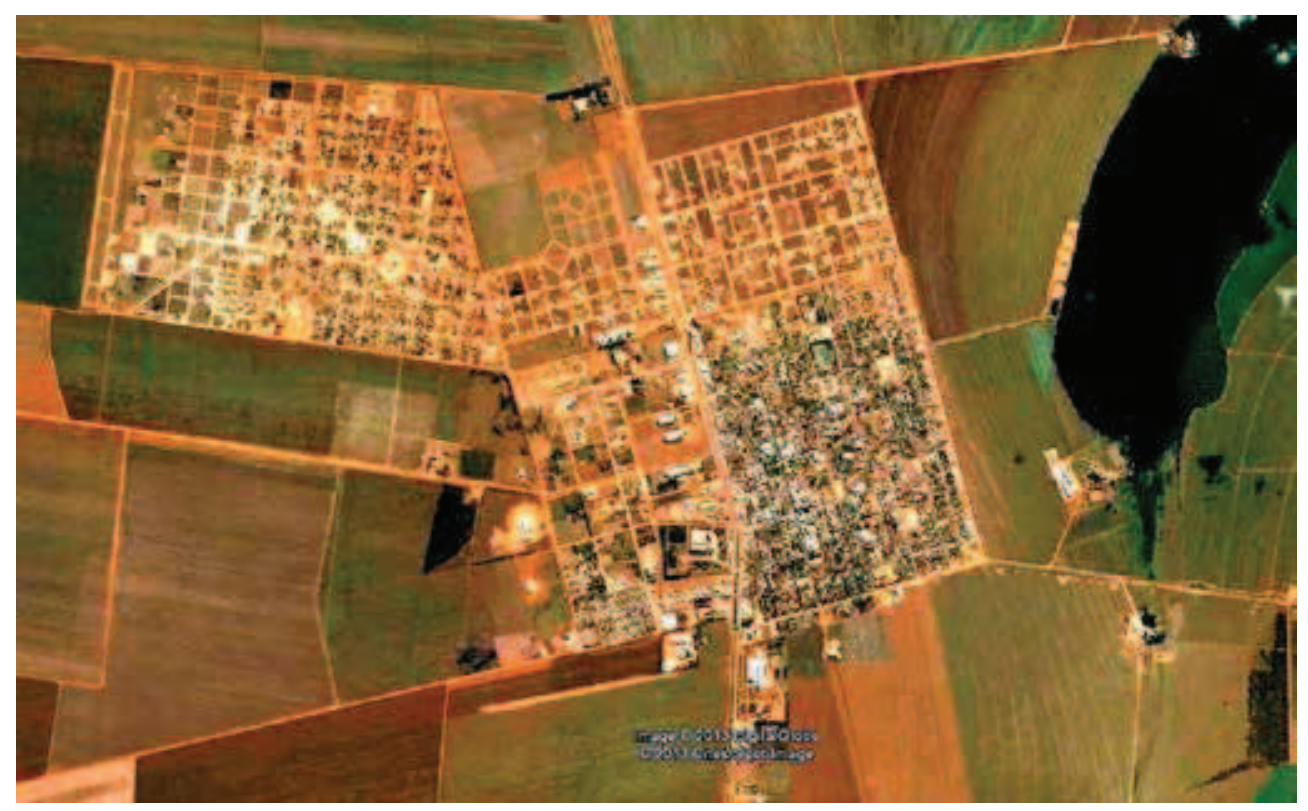

Figura 11 Imagem de Campo Novo do Parecis. Na parte de baixo, à direita, o centro da cidade. Fonte: Google Earth.

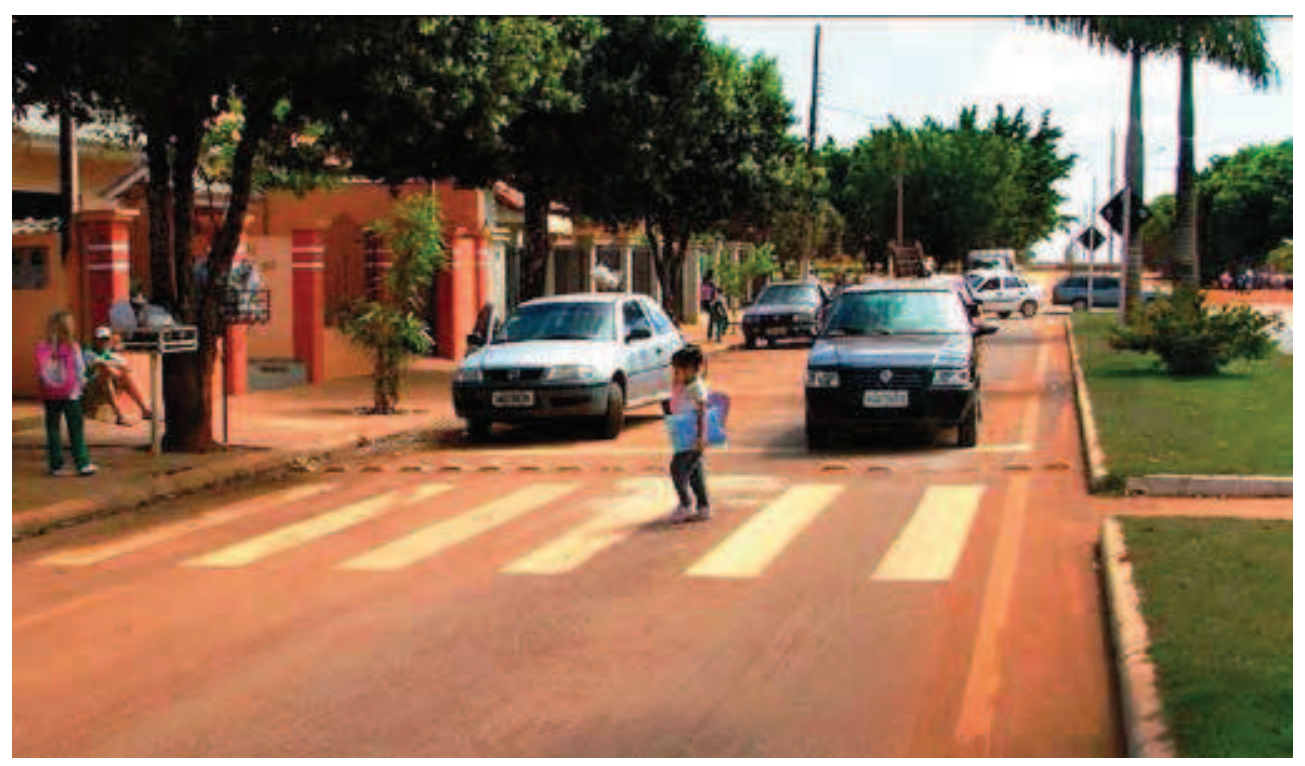

Figura 12 Faixa de pedestre em frente a uma escola pública de Campo Novo do Parecis. Foto: Vicente Barcellos - 2010. 


\section{CAMPO VERDE}

O primeiro núcleo de povoamento do município foi Capim Branco, situado no sopé das chapadas, cujo surgimento ocorreu ainda no final do século XIX, quando chegaram os primeiros habitantes. A região permaneceu vinculada à agropecuária de subsistência até a década de 1970, quando chegaram os primeiros imigrantes vindos do sul, que introduziram o plantio de arroz e fizeram surgir nos altos tabuleiros planos da Chapada dos Guimarães (a 736 metros de altitude), às margens da BR-070 (Brasília-Cuiabá), um posto de combustível - cujo proprietário, anos mais tarde, abriu o primeiro loteamento, dando início à atual cidade no lado sul da rodovia, onde terrenos de relevo mais movimentados acabariam por limitar seu crescimento nessa direção.

Em função disso, Campo Verde acabou se desenvolvendo ao longo da rodovia, onde predominam os usos industriais e os serviços pesados relacionados ao transporte e ao agronegócio, enquanto os usos residenciais e as atividades próprias do centro urbano ficaram no lado norte da rodovia.

Desse modo, seu tecido urbano se constituiu pela justaposição de diferentes loteamentos com traçados muito semelhantes aos encontrados nas demais cidades, ou seja, largas avenidas com canteiros centrais que se cruzam formando praças rotatórias e ruas de menor largura. Em Campo Verde, as boas condições de tratamento e manutenção dos espaços livres públicos chama atenção (figuras 13 e 14).

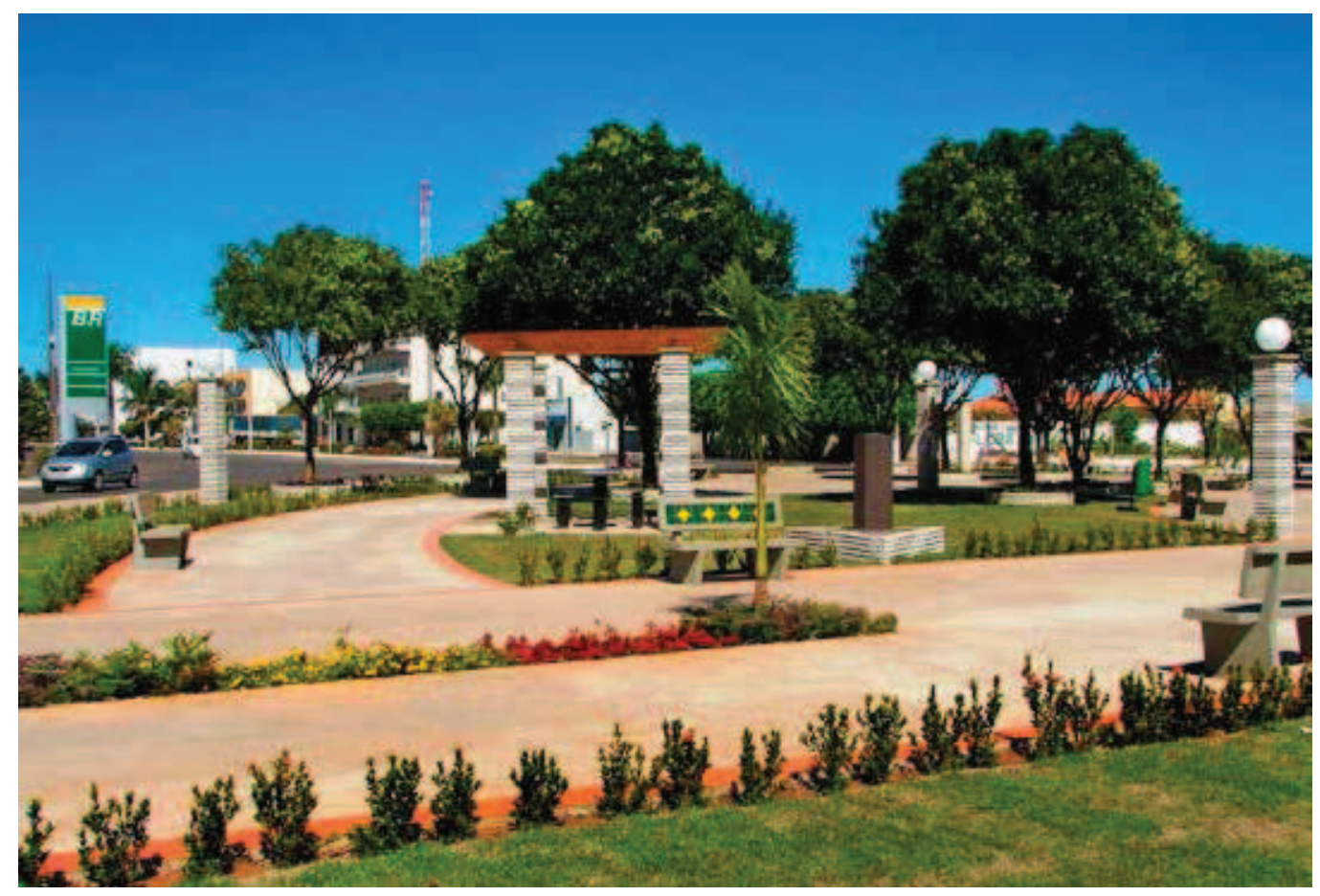

Figura 13 Praça no cruzamento de duas avenidas em Campo Verde. Foto: Vicente Barcellos - 2010. 


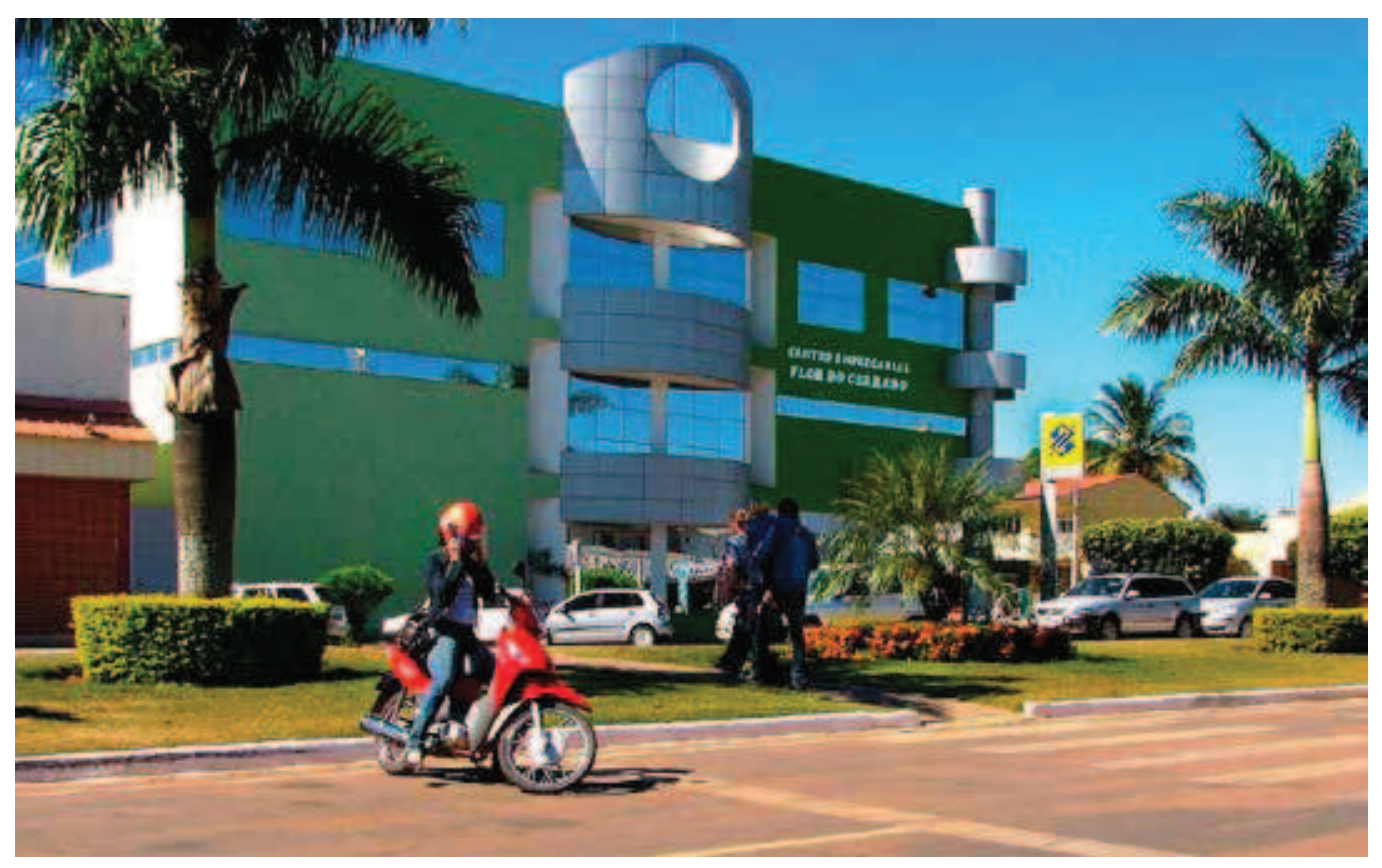

Figura 14 Avenida principal de Campo Verde.

Foto: Vicente Barcellos - 2010.

\section{PRIMAVERA DO LESTE}

O surgimento de Primavera do Leste se deve a um advogado paulista que se estabeleceu na área no início da década de 1970 e, mais tarde, criou um loteamento no cruzamento da BR-070 com a MT-130, abrindo as primeiras ruas da cidade.

Primavera do Leste, tal como Campo Verde, situa-se na borda dos altos tabuleiros da Chapada dos Guimarães a uma altitude de 650 metros. $O$ conjunto do seu tecido urbano é resultado da justaposição de diferentes loteamentos que surgiram a partir do núcleo inicial, no encontro das já citadas rodovias que hoje cortam a cidade e aglutinam, no seu entorno, silos de armazenagem de grãos, agroindústrias e serviços relacionados.

Ainda que a cidade tenha sido constituída por diferentes loteamentos, predominam no tecido urbano as avenidas com canteiros centrais intercaladas por ruas, tal como nas cidades anteriormente examinadas -, embora em Primavera do Leste o dimensionamento das caixas das vias seja menor, resultando em calçadas mais estreitas.

Na medida em que as praças rotatórias têm menores dimensões, não se prestam aos usos de lazer e recreação. Portanto, seria de se esperar a existência de maior número de praças, mas tal não ocorre. Os dois mais importantes espaços livres públicos tratados são: a praça da área central da cidade (figura 15) e o calçadão localizado às margens da BR-070, situação que sugere a importância da rodovia para a cidade. 


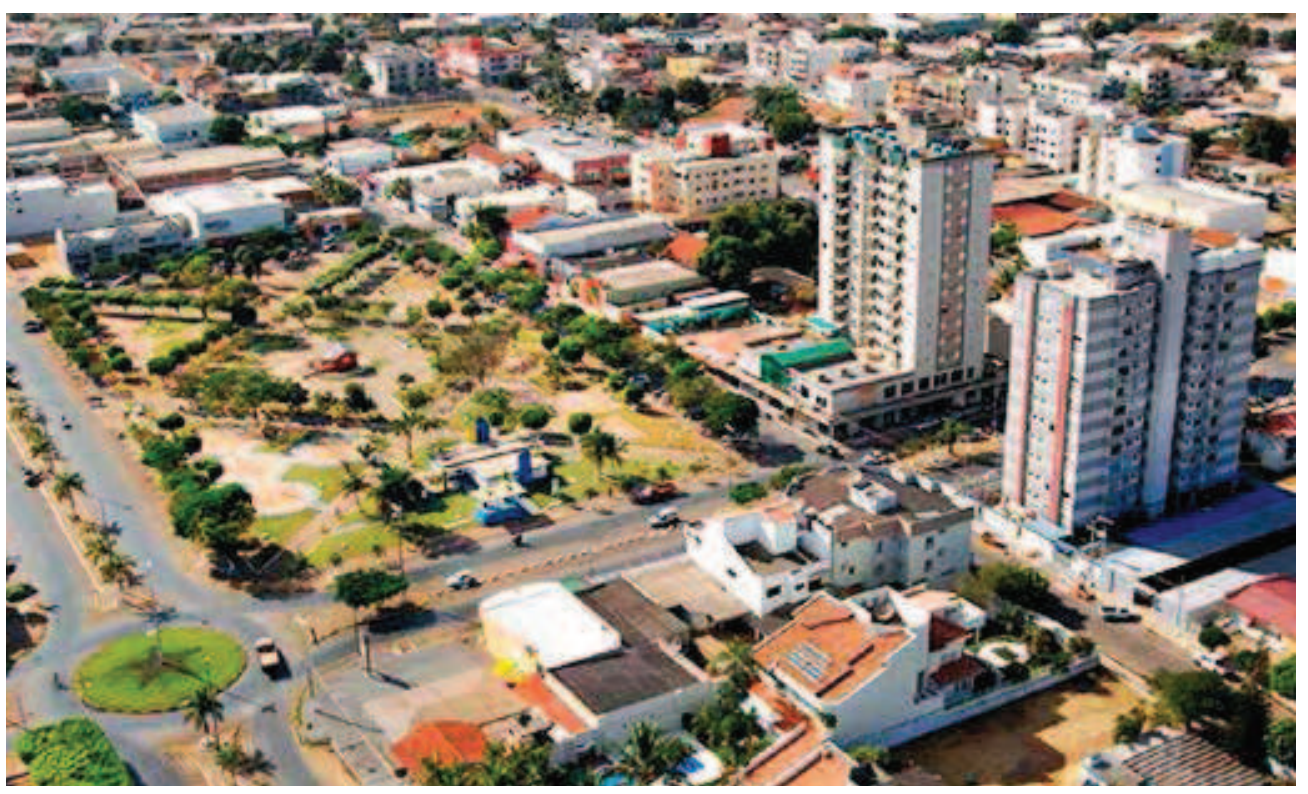

Figura 15 Imagem aérea de praça da área central de Primavera do Leste - 2013.

Fonte: Prefeitura Municipal de Primavera do Leste.

\section{CONSIDERAÇÕES FINAIS}

Na década de 1970, quando as políticas públicas estimulavam a colonização de Mato Grosso e a ocupação de terras tomadas como desocupadas, objetivando o avanço da fronteira agrícola, as perspectivas de desenvolvimento econômico e social da região pareciam pouco críveis e de difícil fixação.

Hoje, o potencial econômico despertado pela produção agrícola parece irreversível, principalmente se consideramos os aumentos das demandas internas e externas pela produção de grãos, que, ao contrário do que se costuma pensar, não se limita à soja, mas inclui expressivas produções de milho, algodão, feiião, sorgo e outros grãos.

Tais produções desempenham importante papel na inserção internacional do país, o que sugere o aprofundamento dos processos econômicos e sociais que vêm ocorrendo na região, cujos reflexos podem ser observados nas cidades aqui estudadas.

Evidentemente, esses processos tiveram altos custos sociais e ambientais, cujos passivos ainda estão pendentes - problemática não considerada no âmbito do presente trabalho, que tem, como limite, o enfoque das condições de organização interna das paisagens urbanas dos municípios referidos, mais especificamente das condições relacionadas aos espaços livres públicos.

Entretanto, não se pode negar que as cidades escolhidas para esse breve exame apresentam boas condições de organização de suas paisagens urbanas, especialmente no que se refere às condições de tratamento e manutenção dos espaços livres públicos de circulação e de fruição da vida social, como é o caso das avenidas, ruas, calçadas, ciclovias, praças e parques - se compararmos tais cidades com a maior parte das cidades de mesmo porte encontradas no interior do país. 
Assim, parece justo concluir que os desenvolvimentos econômico e social gerados pela produção agrícola nos territórios dos municípios estudados têm contribuído para o bom nível de organização de suas paisagens urbanas.

\section{REFERÊNCIAS BIBLIOGRÁFICAS}

BECKER, Bertha. Significância contemporânea da fronteira: uma interpretação geopolítica a partir da Amazônia brasileira. In: AUBERTIN, Catherine (Org.). Fronteiras. Brasília: EdUnb; Paris: Orstom, 1988, p. 18-26.

BERNARDES, Júlia Adão. Modernização agrícola e trabalho no cerrado brasileiro. Scripta Nova: Revista Eletrónica de Geografia y Ciencias Sociales, v. XI, núm. 245 (54). Barcelona: Universidad de Barcelona, 2007, p. 43-51.

CAMPO NOVO DO PARECIS. Prefeitura Municipal de. Disponível em:

<http://camponovodoparecis.mt.gov.br/portal/index.html>. Acesso em: 11 jun. 2013.

CAMPO VERDE. Prefeitura Municipal de. Disponível em: <http://campoverde.mt.gov.br/portal/index.html>. Acesso em: 11 jun. 2013.

COY, Martin. Desenvolvimento regional na periferia amazônica. In: AUBERTIN, Catherine (Org.). Fronteiras. Brasília: EdUnb; Paris: Orstom,1988, p. 27-36.

GUANZIROLI, Carlos Enrique. Agronegócio no Brasil: perspectivas e limitações. In: Textos para discussão - UFF/ Economia, texto 186, abr. 2006. Niterói: Faculdade de Economia da Universidade Federal Fluminense, ISSN 1519 $4612.59 \mathrm{p}$.

INSTITUTO BRASILEIRO DE GEOGRAFIA E ESTATÍSTICA (IBGE/CIDADES). Disponível em:

<http://www.ibge.gov.br/cidadesat/index.php>. Acesso em: 10 mar. 2003 a 11 jun. 2013.

NERI, Marcelo Cortes (Coord.). A pequena grande década: crise, cenários e a nova classe média. Centro de Pesquisa Social, Fundação Getúlio Vargas (CPS/FGV), Rio de Janeiro, 2010. 132 p.

NOVA MUTUM. Prefeitura Municipal de. Disponível em: <http://novamutum.mt.gov.br/portal/index.html> . Acesso em: 11 jun. 2013.

PREFEITURA MUNICIPAL DE LUCAS DO RIO VERDE. Plano Diretor do Município de Lucas do Rio Verde: reavaliação e atualização. Lucas do Rio Verde, 2007.

PREFEITURA MUNICIPAL DE PRIMAVERA DO LESTE. Disponível em:

<http://www.primaveradoleste.mt.gov.br/portal/index.html>. Acesso em: 10 jul. 2013.

PREFEITURA MUNICIPAL DE SINOP. Disponível em: <http://sinop.mt.gov.br/portal/index.html>.

Acesso em: 10 jul. 2013.

PREFEITURA MUNICIPAL DE SORRISO. Disponível em: <http://sorriso.mt.gov.br/portal/index.html>. Acesso em: 10 jul. 2013.

PROGRAMA DAS NAÇÕES UNIDAS PARA O DESENVOLVIMENTO (PNUD). Atlas do desenvolvimento humano no Brasil: ranking do IDH dos municípios do Brasil, 2000. Programa das Nações Unidas para o Desenvolvimento. Disponível em: <http://pnud.org.br/atlas/oque/index.php>. Acesso em: 28 jul. 2013. 
Vicente Barcellos 